\title{
Languages in Public Policy, and Constraints in Academia
}

\author{
Phillipson, Robert
}

Document Version

Accepted author manuscript

Published in:

Language Problems and Language Planning

DOI:

10.1075//plp.00046.phi

Publication date:

2019

License

Unspecified

Citation for published version (APA):

Phillipson, R. (2019). Languages in Public Policy, and Constraints in Academia. Language Problems and Language Planning, 43(3), 286-311. https://doi.org/10.1075//plp.00046.phi

Link to publication in CBS Research Portal

\section{General rights}

Copyright and moral rights for the publications made accessible in the public portal are retained by the authors and/or other copyright owners and it is a condition of accessing publications that users recognise and abide by the legal requirements associated with these rights.

Take down policy

If you believe that this document breaches copyright please contact us (research.lib@cbs.dk) providing details, and we will remove access to the work immediately and investigate your claim. 


\title{
Languages in Public Policy, and Constraints in Academia Robert Phillipson
}

\author{
Journal article (Accepted manuscript*)
}

\section{Please cite this article as:}

Phillipson, R. (२०19). Languages in Public Policy, and Constraints in Academia. Language Problems and Language Planning, 43(3), 286-311. https://doi.org/10.1075/Iplp.00046.phi

DOl: https://doi.org/10.1075//pp.00046.phi

* This version of the article has been accepted for publication and undergone full peer review but has not been through the copyediting, typesetting, pagination and proofreading process, which may lead to differences between this version and the publisher's final version AKA Version of Record.

(C) John Benjamins. This article is under copyright is under copyright and that the publisher should be contacted for permission to re-use or reprint the material in any form.

Uploaded to CBS Research Portal: August २०२० 
Languages in public policy, and constraints in academia

Language Problems and Language Planning, 43/3, 2019, 286-311, a rejoinder

by Jacques Mélitz, and a response by Robert Phillipson, 318-324.

\author{
Robert Phillipson \\ Copenhagen Business School, Denmark \\ www.cbs.dk/en/staff/rpmsc
}

\title{
ABSTRACT
}

The article explores evidence of public policy ignoring scholarly recommendations, and describes instances of this in the field of language policy at both supranational and national levels. One significant contemporary influence is that university autonomy and academic freedom are being constrained by neoliberal pressures. Evidence of this in the United Kingdom and Denmark is described. These trends are connected to the wider context of the transition from the practices and ideology of terra nullius to legitimate colonisation and global Europeanisation, and the concomitant dispossession of the territories of others, to global Americanisation processes, the universalization of a cultura nullius in commerce, the media, academia, and domestic life. This dovetails with the promotion and establishment of English as a lingua nullius, a language that should be learned by all worldwide, as if it serves the interests of all inhabitants of the globe, and is disconnected from the causal factors behind the expansion of the language. One speech by Winston Churchill argues for the maintenance of university autonomy and historical awareness. Another pleads for Anglo-American global dominance, including the promotion of English as a 'world' language. These competing pleas have had different outcomes: academic freedom and traditions are currently at risk, whereas US dominance and the promotion and expansion of English have thrived. The governments of the five Nordic countries have acted to ensure the maintenance of national languages as well as competence in 'international languages'. This is exemplified by a description of how universities should assure parallel competence and thereby a healthy balance between English and national languages. Soft power is never far from economic, political, and military power, all of which entail language use. China and Chinese are well launched on a comparable trajectory to the expansion of English. ${ }^{1}$

\section{Public Policy at universities}

Here is a voice from the mid-20 th century:

The first duty of a university is to teach wisdom, not to train, and to confirm character and not impart technicalities. We want a lot of engineers in the modern world, but we do not want a world of engineers. We want some

\footnotetext{
${ }^{1}$ An earlier version of this article was produced for participants in EU-funded research on Migration and Inclusion in Multilingual Europe (MIME), at a project meeting in Brussels in June 2018, see http://www.mime-project.org.
} 
scientists, but we must make sure that science is our servant and not our master... No amount of technical knowledge can replace the comprehension of the humanities or the study of history and philosophy.

The advantages of the nineteenth century, the literary age, have been largely put aside by this terrible twentieth century with all its confusion, exhaustion, and bewilderment of mankind. This is a time when a firm grip on all the essential verities and values of humanity and civilization should be the central care of the universities of Europe and the world.

These words were pronounced at the University of Copenhagen by Winston Churchill in 1950 when he was awarded an honorary doctorate. This was granted on the strength of UK support for Denmark in World War II and of Churchill's historical writings. His lecture makes questionable claims about history, but his understanding of what universities should do is relevant in the $21^{\text {st }}$ century, which is also characterised by 'confusion, exhaustion, and bewilderment'. Churchill's engineers have been replaced by economists and bankers, whose neoliberal capitalist tunnel vision has created a world of indefensible global and local inequalities, while the principle of the university as a public good is being undermined.

Political leaders in the modern world are 'pygmies' ${ }^{2}$ in the assessment of the eminent historian Tony Judt (2010: 164). Capitalism creates winners and losers, nationally (classes) and internationally (USA, China, Germany,...). While big corporations and the rich 1\% thrive, much of the world is being impoverished. There has been a dramatic shift to the right in many countries, with extreme movements and parties becoming influential. Nationalist governments erode democratic principles, particularly in former communist countries in eastern and central Europe, e.g. Poland, Hungary, and Slovakia. Meanwhile in many western European democracies, including France, Germany, Greece, Italy, Spain, and the Nordic countries, mainstream political parties are losing influence. Nativist rightist movements have activated the racism that has always been present in European societies but made it more public and seemingly respectable (Fekete 2018). Xenophobic parties are increasingly influential in Denmark, Finland, Norway and Sweden, as in other parts of Europe.

Movements for political, social, and linguistic justice have achieved some success, but are vulnerable worldwide. The revitalisation of marginalised languages is occurring worldwide (Olthuis, Kivelä and Skutnabb-Kangas 2013, SkutnabbKangas and Phillipson 2017, Hinton, Huss, and Roche 2018). The European Union (EU) has some major accomplishments, but is constitutionally committed to market economics. The handling of many crises - the euro, refugees, political turbulence in many member states, disaffection with the European project as visible in failure to exercise the right to vote in European Parliament elections has revealed major weaknesses in the European project. Its language rights commitments are weak. The management of multilingualism in its institutions, through translation and interpretation is effective for many purposes, but many

\footnotetext{
2 This metaphor implies smallness of vision, and should not be understood as a racist slur on one section of humanity.
} 
of its activities, 'actions', and language policy recommendations contribute to English linguistic hegemony (Phillipson 2003, 2016a).

At the interface between research-based public policy and policy implementation there is a significant gap. The European Union's Chief Scientific Advisor from 2012 to 2014, Ann Glover, experienced that the European Commission's political agenda often conflicted with the scholarly evidence submitted to it. She noted that in several high-profile policy areas, evidence was manipulated, and scholarly input subordinated to political goals. Facts were "twisted"3. The abolition of the post of EU Chief Scientific Advisor by the Commission's President, Jean-Claude Juncker, in $2014^{4}$ shows that the meso level of scholarship is trumped by macro level economic and political forces.

How the EU system works, and in particular Juncker's attitude to it, was reported in The Economist, in a shocking revelation of the EU's democratic deficit:

We decide on something, leave it lying around, and wait and see what happens. If no-one kicks up a fuss, because most people do not know what has been decided, we continue step by step until there is no turning back. ${ }^{5}$

In the language policy field, the same clash between truth-based knowledge and political decision-making takes place. For instance, the recommendation that two foreign languages should be taught in primary schools, and the dogma that 'the earlier foreign languages are learned, the better the results', which has been preached by the EU for decades, are invalid recommendations unless many pedagogical conditions are met, which they seldom are ${ }^{6}$. This has been pointed out to the European Commission by expert advisers, but inconvenient scholarly input is simply ignored.

Another clear instance of the EU not acting on policy recommendations is a Feasibility Study to investigate a broad range of language policy issues. It was requested by the European Parliament, and commissioned by the DirectorateGeneral for Education and Culture. The task was given to a consultancy with wide experience of servicing EU institutions. Its detailed study, of 18 May 2005 (118 pp.), drew on extensive consultation with a wide range of people concerned with many aspects of language policy, and was available on the DG's website. It analyses needs, conditions, and modalities, and confirms that a wealth of professional expertise exists that decision-makers ought to draw on. It makes a strong case for either a Linguistic Agency, like other high-prestige EU agencies

\footnotetext{
${ }^{3}$ http://www.euractiv.com/, 27 May 2014. Her own advice to the Commission president is not made public.

4 https://www.theguardian.com/science/political-science/2014/nov/13/juncker-axeseuropes-chief-scientific-adviser

5 Reported by Chris Patten, EU commissioner for the UK 1999-2004, in his autobiography (Patten 2005, 122).

6

See Phillipson 2003, Enever and Lindgren, eds., 2017, and Phillipson 1992, chapter 6 on five language pedagogy fallacies.
} 
(dealing for instance with the Environment in Copenhagen, and Fundamental Rights in Vienna), or alternatively a network of Language Diversity Centres to strengthen policy formation and implementation, particularly for regional minority languages. The study revealed a widespread perception that there is a serious need for policy advice and information for national and EU decisionmakers. This was overwhelmingly the case in new member states, whereas the established ones considered such functions 'not useful'. There was also near unanimity in responses in rejecting English as a sole lingua franca. The study concludes that 'A no-action scenario would seriously undermine the credibility of the EU in this field'.

In fact the Linguistic Agency and network proposals were rejected unilaterally by the Commission. It is impossible to know on what grounds, but if an agency had been established, there would necessarily have been a reduction of the freedom of manoeuvre of the Commission and its ability to determine language policy overtly in its 'actions', and covertly through the laissez faire that essentially strengthens English and other dominant languages.

It is significant that in 2018 the European Ombud announced a public consultation on the management of multilingualism in the 'EU's institutions, bodies, and agencies', including whether there is a need for more explicit policies for choice of language on EU websites, for public consultations on key issues, etc. ${ }^{7}$. It follows a thorough study commissioned by the European Parliament's Culture and Education Committee, 'European study for Multilingualism: Benefits and Costs', produced by Michele Gazzola in $2016^{8}$. This analyses the goals of the European Strategy for Multilingualism, measures for assessing or achieving them, and, based on a wealth of statistical data, explains why many desirable goals remain unmet. For instance it documents that the idea of English as a 'basic skill' is a myth, since only 7\% of continental Europeans report that their competence in English is 'at a very good level'.

An example of public policy at the national level comes from Sweden in the 1990s. A multidisciplinary team of researchers conducted a major investigation of minority language rights in education. A policy studies specialist in the team concluded her survey of scholarly research data, and of implementation, with the rueful comment: 'at a decision-making level, scientific "truths" are often subordinated to economic "truths" ' (Municio-Larsson 2000). Macro forces ignore meso and micro level evidence. A more recent comparative study of minority mother-tongue instruction in Sweden and Denmark distinguishes, following Bourdieu, between the political field, the academic field, and the bureaucratic field (Salö et al 2018). It concludes that whereas in Denmark there is no tradition of politicians commissioning studies by academics, or of decisions being informed by scholarship, this is standard practice in Sweden, which has

\footnotetext{
7 https://www.ombudsman.europa.eu/en/correspondence/en/99005.

8 http://www.europarl.europa.eu/supporting-analyses.
} 
therefore had more enlightened policies for minority mother tongues, even if implementation is far from ideal. ${ }^{9}$

The Swedish government has commissioned comprehensive language policy studies to assess whether English represents a threat to Swedish or not. A large body of evidence, analysis, and possible scenarios was collated. It was sent out widely to monitor public reactions (local and national government, minority associations, trade unions, academia etc.). Evidence submitted was processed by the Ministry of Justice and published. There ensued follow-up legislation in 2009 aimed at consolidating Swedish nationally and in the EU system, and identifying five national minority languages. Implementation of its principles has seriously lagged behind, as shown in a magisterial follow-up study, also commissioned by the government (Lainio, Nordin and Pesonen 2017).

This is a work of 654 pages, including a summary in English (pp. 333-43). Booklength studies are unlikely to be read by politicians or bureaucrats, whether national or supranational. I wrote the book English-only Europe? Challenging language policy in 2003, aiming at the general public, and hoping that it would be read in government circles and in EU institutions ${ }^{10}$. The book makes a strong case for maintaining the vitality of all European languages. The concluding chapter sketches out worst- and best-case scenarios, followed by 41 recommendations for action. It includes a warm recommendation by the then Vice-President of the European Commission, Neil Kinnock, though whether he used his influence to promote multilingualism in the Commission is unknown but improbable. I suspect that the book has only had a scholarly readership. The interface between academia and political systems is slippery. The market forces that determine policy are rock hard.

This reality means that when and if Brexit takes effect, there will very probably be no reversal of the dominance of English in EU institutions as the main language in-house and in external affairs ${ }^{11}$. The other EU countries with English as one of their official languages, Ireland and Malta, will continue using mainly English, as will eurocrats. The pre-eminence of English is a fait accompli that has little to do with what the UK does. There is unlikely to be a massive increase in the use of French, as advocated by Président Macron ${ }^{12}$, and endorsed by Jean-

\footnotetext{
9 This might lead one to conclude that Danish politicians are uninterested in evidence, whereas Swedes are, but may ignore it. By contrast there is anecdotal evidence that Chinese academics are permitted to research any conceivable topic, but they are not allowed to publish it.

${ }^{10}$ A translation, with updating, into French was published as La domination de l'anglais, un défi pour l'Europe, Paris: Libre \& Solidaire, in March 2019.

11

The journal World Englishes published a thematic number, volume 36/3, 2017, on the linguistic consequences of Brexit, but the lead article by Marko Modiano that contributors were asked to relate to was a far from ideal presentation of the issues, as my response demonsrates (Phillipson 2017).

12

https://www.lemonde.fr/politique/article/2018/03/20/emmanuel-macron-la-francophonie-est-unesphere-dont-la-france-n-est-qu-une-partie_5273810_823448.html. Macron also aims to make French the primary language of Africa.
} 
Claude Juncker ${ }^{13}$. But with the EU currently crisis-ridden, perhaps there is an answer looming to the question that I end my book with: 'If inaction on language policy in Europe continues, at the supranational and national levels, we may be heading for an American English-only Europe. Is this what the citizens and leaders of Europe want?' (Phillipson 2003, 192). As Gramsci reminds us, linguistic hegemony is symbiotic with political, economic, and social dominance. Language policy needs to be approached holistically. American influence throughout Europe is ubiquitous but is also resisted.

Some governments are managing current language policy challenges insightfully, as will be seen below in the example of cooperation between the five Nordic countries (Scandinavia and Finland) on higher education language policy. This builds on substantial cooperation between academia and governments. On the other hand, policy implementation tends to be weak. Academic freedom and university autonomy have traditionally been strong in the Nordic countries, but they are at risk. One factor is how researchers see their role, and the choices that are open to them. Pierre Bourdieu saw academics as having three choices (1989, 486): remaining closeted in an ivory tower, conducting research on topics that have been selected by those in power, or using university autonomy to address and influence key socio-political issues, in the classic role of the intellectual ${ }^{14}$. In the $21^{\text {st }}$ century being able to select the third option is becoming increasingly difficult, since the role of universities is being redefined.

\section{The roles of a university}

Universities are under massive pressure to change. The overall pattern in Europe replicates trends in the USA and Canada, with universities subject to neoliberal market forces, an expansion of 'for profit' institutions, and escalating student fees (Spooner and McNinth, eds., 2018). In the USA two-thirds of university staff do not have tenure and are on short-term contracts (Collini 2017). Many of these traits can be seen in Europe.

Trends in higher education in the UK have been analysed in several in-depth studies, which Stefan Collini, a Cambridge University authority on intellectual history, draws on in an impassioned denunciation (2017).

Collini's rich canvass illustrates how universities have been changed:

\footnotetext{
13 https://www.euractiv.com/section/french-language/news/macron-says-too-much-englishspoken-in-pre-brexit-brussels/.Juncker also argued for the intrinsic superiority of French, a classic myth.

${ }^{14}$ L'alternative est claire, en effet, bien qu'elle soit très rarement perçue : ou bien accepter l'une ou l'autre des fonctions sociales que la nouvelle définition sociale impartit aux producteurs culturels, celle de l'expert, chargé d'assister les dominants dans la gestion des "problèmes sociaux", ou celle du professeur, enfermé dans la discussion érudite de questions académiques; ou bien assumer efficacement, c'est-à-dire avec les armes de la science, la fonction qui fut remplie longtemps par l'intellectuel, à savoir d'intervenir sur le terrain de la politique au nom des valeurs ou des vérités conquises dans et par l'autonomie. Pierre Bourdieu, 1989: 486.
} 
- The idea of a university has been corrupted by subordination to shortterm instrumental, reductive, generally economic goals.

- Students are seen less as seekers after truth and knowledge and more as consumers.

- The evaluation of research, and of concomitant funding, focuses on 'impact' factors that have little bearing on how research quality is generated.

- A small number of 'elite' universities are exceptionally well funded, while a large number of poorly funded institutions have limited research capacity.

- Quality in dynamic departments has been undermined by the creation of ever larger inter-disciplinary units.

- Administration has become top-down management inspired by principles from commerce.

- Universities are run as businesses and no longer receive government funding for teaching activities. Foreign students pay exorbitant fees, while most British and EU students take on large loans to cover fees.

- Reliance on market forces results in essential subjects, especially in the humanities, being eliminated for short-term financial reasons.

- An excessive number of 'for profit' institutions of dubious quality are entitled to call themselves universities. As in the USA, venture capital involvement and shareholder expectations are undermining academic autonomy and self-definition.

Collini concludes (ibid., 212) that 'Britain is the guinea pig in an experiment in extending free market dogmas in higher education', one that continental European countries may well copy, even if the managerialisation of universities has not yet reached the same level.

These 'modernisation' dogmas are directly visible in the massive closure of foreign language departments. This is a fait accompli in the UK and Denmark, despite a strong case for foreign languages being made eloquently in both countries, in abortive attempts to influence public policy ${ }^{15}$.

In Denmark university boards of management have a majority of non-academics, often people from the business world. The Royal Danish Academy of Sciences and Letters documented in 2007 the way academic freedom was 'controlled' rather than 'real'16 . In 2008 the trade union of Danish academics used the UNESCO appeals procedure to complain about academic freedom being undermined $^{17}$. Tenure no longer exists. Higher education is government-funded.

${ }^{15}$ See http://www.nuffieldfoundation.org/nuffield-languages-inquiry-and-nuffield-languagesprogramme for the UK. For Denmark see Phillipson 2001. Several official reports since then were not acted on. For a major hearing and recommendations see Verstraete-Hansen and Phillipson 2008. Verstraete-Hansen and Øhrgaard 2017 is an eloquent cri de coeur.

16 The distinguished Danish intellectual, Jørn Lund, a member of the Senate of the University of Copenhagen, in the daily paper Politiken, 7 April 2007.

17

Since all UN bodies, including UNESCO, represent states, the complaint was investigated but the 
All degrees have to be vetted by the Ministry of Higher Education and Science, and to justify their existence in relation to assumed job prospects ${ }^{18}$.

An extreme case of the failure to protect vulnerable subjects with a small student intake is the eradication of all foreign languages at Copenhagen Business School. CBS is an institution with university status and a century-old faculty of foreign languages that has met the needs of business and government for translators and interpreters, primarily of the main European languages. Over the past decade, management has emulated the profile of Anglo-American business schools. Financial constraints, market 'logic', and the absence of any national planning for foreign languages in Denmark, have led to the progressive elimination of foreign languages at CBS, initially Russian and Italian and specialist degrees in translation. In 2017 English, French, German, Spanish and Japanese were scrapped. English remains as a corporate language alongside Danish, and increasingly the dominant language of all CBS activities ${ }^{19}$.

This devastation has taken place despite regular protests by scholars with insight into language policy studies and Danish needs. These, as the corporate world knows well, are substantial, just as the legal and medical professions are acutely in need of qualified translators and interpreters. The decision to eliminate all foreign languages is even in conflict with the statutes for CBS, which commit the institution to conduct research and teaching at the highest international level in both business economics and foreign languages for commerce $^{20}$. The board is supposed to oversee that the regulations are followed, which has not happened. The rule of law is ignored by those who can get away with it ${ }^{21}$.

This example of short-term, misguided university management should serve as a warning that catastrophes in the handling of language policy can take place even in a country that sees itself as open, democratic, and progressive. It exemplifies how university autonomy and the principle of higher education as a public good have been undermined by top-down managerialism ${ }^{22}$. Danish policy reflects an excessive reliance on market forces and the example of the USA, whether in

18

only outcome was encouraging academia and the Danish government to collaborate.

Civil servants with experience in the Ministry of Finance are increasingly reallocated to other

19 Com istries, exemplifying the key role of economists in all societal fields.

There is a much smaller business school in Jutland as part of Århus University where four foreign languages are still taught.

20

My translation of 'erhvervsøkonomi og erhvervssprog' in CBS's statutes. After the abolition of foreign languages, the regulations were changed so as to exclude foreign languages.

21

In the wake of Shakespeare's Hamlet, it is tempting to conclude that something is again rotten in the state of Denmark- now in language policy. Hopefully ghosts will haunt those responsible.

22

In 2011 the Rektor of CBS, after two years in post, was sacked as a result of senior staff staging a legitimate in-house revolution. The turbulence was directly related to inappropriate top-down management. The chair of the board of CBS, a senior industrialist, was also forced to resign because of his role in selecting and liaising with a Rektor with dubious leadership skills. A theoretically informed analysis of the process portrays how and why the revolt was successful (Christensen 2016). 
waging war, privatising public services, or projecting consumerist life-styles. Denmark's policies vis-à-vis immigrants and refugees have been hostile for over 30 years: a precondition for inclusion is cultural and linguistic assimilation (Salö et al 2018).

Successive Danish governments have basically acted as though English is the only foreign language worth seriously bothering with, even if competence in many languages is crucial for a demographically small country. Germany is a key export market, massively influential in the EU, and has had a decisive influence on Denmark over several centuries. Young people have been so massively influenced by Americanisation that few choose to specialise in German or other foreign languages in higher education. Recognition of a national crisis led the government in 2018 to establish two 'national centres' with a mandate to reanimate foreign language learning ${ }^{23}$. At the micro level, some constructive efforts are undertaken to soften government policies: several foreign languages are still learned in schools; some local authorities do offer mother-tongue learning for immigrants, without financial support from the government.

\section{From terra nullius to cultura nullius}

We need to see our past and present in a historical perspective, to analyse the 'longue durée' (Braudel), the macro level of structures and ideas that develop slowly over time. We can begin by looking at the way global Europeanisation was legitimated, and continue by exploring how the $20^{\text {th }}$ century became the American century, as proclaimed by Henry Luce in Time on 17 February 1941, confirming United States exceptionalism and the myth of a 'manifest destiny' to assert its power and impose its will globally.

The British philosopher John Locke provided a rationalisation for Europeans arrogating to themselves a God-given right, endorsed by the Pope in Rome, to occupy territory elsewhere. This entailed the dispossession and genocide of local inhabitants that nearly all western European states perpetrated. Locke himself 'owned stock in slave trading companies and was secretary of the Lords Proprietors of the Carolinas, where slavery was constitutionally permitted.' (Uzgalis 2017, McCarthy 2009, Patel and Moore 2018).

In the chapter on Property in Two Treatises of Government, 1690, Locke argues that God commanded people to labour, as a result of which they can increase their possessions: 'God, by commanding to subdue, gave Authority so far to appropriate' (1988: 292). Since the indigenous peoples of America have failed to labour, 'they are rich in Land, and poor in all the Comforts of Life'. Nature has given them the same resources as people elsewhere, and productive territory, but they 'for want of improving it by labour, have not one hundredth part of the Conveniences we enjoy' (ibid., 296-7). From which, Locke draws the conclusion that: 'In the beginning, all the World was America, and more so than it is now; for no such thing as Money was any where known.' (ibid., 301). The fruits of labour

${ }^{23}$ These are at Copenhagen and Aarhus Universities, three staff at each. 
can be converted into gold, silver, or money, which can then be used as a way of legitimating 'disproportionate and unequal Possession of the Earth', this inequality being, in Locke's claim, 'tacitly but voluntarily' agreed on by society (ibid., 302).

This argument was supposed to justify European colonisation and to sanctify Christian proselytisation. Land, in what became named the Americas, was terra nullius, land supposedly belonging to no-one, to which its benighted inhabitants had no claim or rights. The ideological foundation for this argument is the dichotomy between us (the "civilised") and them (the "barbarians") that has been deeply rooted in the thinking of the Western world since the time of the ancient Greeks. Occupying lands deemed to be terra nullius is a key feature of the racism that Europeans instrumentalised worldwide and have still not resolved or eliminated effectively in the Americas or Europe.

Terra nullius in international law signifies land to which no-one holds legal title. Cultural and linguistic expansion do not occupy vacant space but are necessarily in competition and conflict with local practices. Terra nullius doctrine and racism has been succeeded by the cultura nullius of global Americanisation, a process already noted by George Bernard Shaw a century ago ${ }^{24}$, and English as a lingua nullius, both of which can lead to local dispossession.

President George Washington envisaged the USA as 'a rising empire'. Presidents from Calvin Coolidge in 1925 to Donald Trump have acted on the principle that 'The chief business of the American people is business'. President Harry Truman proclaimed in 1947 that 'The whole world should adopt the American system. The American system can survive in America only if it becomes a world system'. This was reaffirmed by President Barack Obama in 2014. 'Here's my bottom line: America must always lead on the world stage. ${ }^{25}$

In the cultural Cold War, all western European countries experienced massive efforts by the USA, often funded by the CIA, to project Hollywood, and influence intellectuals, reading habits, and cultural and political life (Saunders 1999). In occupied territories such as Austria, de-nazification involved systematic efforts to Americanize education and health systems as well as intellectual and political norms (Wagnleitner 1994). McDonaldisation (Hamelink 1994, Ritzer 2011) has penetrated academia, the business world, the media, advertising, lifestyles, entertainment and clothing in countless ways. Neoliberal commodification principles permeate cultural norms. Consumerist capitalism of the American kind is projected as a cultura nullius of universal relevance, a necessity in the modern world (Kayman, 2004). A detailed analysis of how these processes have taken place is presented by a leading French intellectual, who stresses the key role of American leadership in technology and the media for the americanisation of France (Debray 2017).

\footnotetext{
24 Shaw, born in 1856, noted this in 1912 (Holroyd 1997).

25 For sources and more detail see Phillipson 2014, 2016c, 2017.
} 
Soft power refers to cultural links, the media, education policies, scholarships, and language learning and teaching, all of which contribute to achieving influence. Soft power has been well documented since the time of the Roman occupation of the British Isles, and in the linguistic imperialism that accompanied global Europeanisation. The term soft power implies divorce from cruder forms of power, military, political, and economic, though these invariably loom in the background and in fact viscerally interlock with soft power. Talk of soft power serves to sanitise neocolonial exploitation of resources and labour. It permeates 'development' activities, and the worldwide promotion of English by 'English-speaking countries' (a term that occludes their multilingualism), the BANA countries (Britain, Australasia, and North America).

Universities play a major role in producing experts (pace Churchill) and training teachers. While foreign languages are languishing in BANA countries, linguistics, applied linguistics, and a specialisation in teaching English to foreigners have expanded dramatically from the mid-1950s. Understanding this development requires a historical explanation not merely of the dominance of US power but also of how and why 'world' English emerged ${ }^{26}$.

\section{'World' English the lingua nullius ${ }^{27}$.}

The promotion of English has been Anglo-American policy since the 1930s. When Winston Churchill was awarded an honorary doctorate at Harvard University on 6 September 1943, he laid out a vision of a post-fascist world, with English playing a dominant role $^{28}$.

The power to control language offers far better prizes than taking away people's provinces or lands or grinding them down in exploitation. The empires of the future are the empires of the mind.

This gift of a common tongue is a priceless inheritance, and it may well some day become the foundation of a common citizenship. I like to think of British and Americans moving about freely over each other's wide estates with hardly a sense of being foreigners to one another. But I do not see why we should not try to spread our common language even more widely throughout the globe and, without seeking selfish advantage over any, possess ourselves of this invaluable amenity and birthright.

Global English was one of five themes in his speech, the others being UK/US unity, military collaboration, plans for global peace-keeping, and ensuring US/UK global dominance. Churchill was speaking at a time when the survival of Great Britain was uncertain, and depended on US financial and military support. Seeing the promotion of English worldwide as the birthright of the British and

\footnotetext{
26 In the Encyclopedia Britannica of a century ago, international languages referred exclusively to planned languages like Esperanto and Volapük.

${ }^{27}$ For more detailed elaboration of lingua nullius, see Phillipson 2018. 28

In several important speeches in the 1940s, and in his popular books on 'The English-speaking peoples', Churchill's vision for the British Empire and connection to the USA and Europe were presented, see Kenny and Pearce 2018, 38-60.
} 
Americans is pure imperialist rhetoric. The five policy variables identified by Churchill were later embodied in the notion of a US-UK 'special relationship', the UN, NATO, a unified European market, and global English. These are key macro level influences that have become well established and continue during the $21^{\text {st }}$ century.

All British Prime Ministers have accepted US dominance. A Margaret Thatcher Center For Freedom was housed for many years at the right-wing nationalist Heritage Foundation in Washington DC. It had as its goal to ensure that the US and UK can 'lead and change the world' ${ }^{29}$. Many factors influenced the outcome of the referendum in the UK on leaving the UK, but there was no clear idea of what the consequences might be, and no plan for what might replace EU membership. One idea that influenced British politicians campaigning to exit the UK from the EU is a belief in an Anglosphere, a union of 'white' Commonwealth countries (Australia, Canada, New Zealand) and the USA in world leadership. This notion has a century-old pedigree in the UK, and reflects imperial fantasy and nostalgia (Kenny and Pearce 2018).

After the First World War the US had limited influence in global affairs (apart from dominating the Americas and the Philippines), since Congress voted against US membership of the League of Nations. President Franklin D. Roosevelt was determined that this should change after the Second. He stated in 1942: 'We have profited by our past mistakes. This time we shall know how to make full use of victory', meaning to conquer enemies and allies alike. Eisenhower in 1950, before he became president, argued in London for a European Common Market. The establishment of the EU was an American project as well as a European one, articulated in US think tanks during the Second World War (Winand 1993, Holm 2001), where key founders of the EU like Jean Monnet were located.

The first conference on 'The use of English as a world language' was held in 1934 in New York, with Carnegie Foundation funding. Agreement was reached on the goal of 'spreading English "as a world language" on a basis of UK-US collaboration' (Smith 2003a and b, italics added). This led to US funding of activities on both sides of the Atlantic in the 1930s and again in the 1950s, and the creation of departments of applied linguistics and the English Language Teaching profession (Phillipson 1992, 2009). Key professional organizations like TESOL (the Teaching of English to Speakers of other Languages) in the US, and IATEFL (International Association of Teachers of English as a Foreign Language) in the UK, were initially national bodies, but now project themselves as 'global'. President Obama launched 'English for all' in 2016, a multi-institutional effort to recruit US young people to teach English worldwide ${ }^{30}$.

\footnotetext{
${ }^{29}$ The Foundation has deleted information about the Center from its website, but a new centre is being established in the UK to further the neoliberal Anglo-American goals that Thatcher stood for (https://www.thatchercentre.com).

30

See https://exchanges.state.gov/us/english-all. 'English for All is the culmination of this administration's drive to promote English language skills globally. English language instruction programs include the State Department Fulbright English Teaching Assistant Program, English Language Specialist Program, and English Language Fellow Program, as well as the Peace Corps
} 
A significant player in this billion-pound industry is the publishing business, which produces textbooks and reference books that are marketed worldwide. Also of major significance are the very influential language proficiency tests (Cambridge, TOEFL, IELTS, etc.): for instance IELTS is now taken by over 3 million people worldwide annually. The professional expertise in question in this industry is projected as universally relevant. Continental European traditions of learning English effectively were excluded from the Anglo-American English learning paradigm. This is monolingual and monocultural, ignoring contrastive analysis of the source and target language, and excluding translation (Phillipson 1992).

International education and English promotion can be seen as an AngloAmerican professional service activity aiming at setting 'global standards in particular professional areas', in spreading 'best practices', and facilitating a global economic system driven by notions of the 'knowledge society', 'universal' economic laws, and global governance. The EU's activities worldwide follow a similar logic, for instance when establishing offices in many non-European countries, and when extending the Bologna process to universities outside Europe. These activities take place almost exclusively in English. The European Commission's budget proposals for 2021-2027 envisage the extension of Erasmus+ activities 'to the world' ${ }^{31}$. It is doubtful whether languages other than English will figure prominently in these. This supranational activity dovetails with universities in the main English-speaking countries establishing affiliates in Asia, the Middle East, and elsewhere. These function as profit-making export businesses selling higher education degrees that have the same content and language as back home. They function monoculturally and monolingually. The rapid expansion of 'international' schools worldwide, leading to university studies in the Anglo-American core (Wechsler 2017) ${ }^{32}$, is part of the same cultura nullius and lingua nullius thrust.

Among the most influential professional service firms are the big four accountancy businesses, Ernst and Young, KPMG, Deloitte, and PriceWaterhouseCoopers, which in 2016 were active in 150 countries, with a staff of 890,000 people. This was 'more than the five most valuable companies in the world combined' (Brooks 2018) ${ }^{33}$. In addition to auditing, they function as

\footnotetext{
Volunteer and Peace Corps Response Volunteer programs. The U.S government also provides online American English tools and resources for both teachers and learners on Facebook'. 
consultants on finance, company law, taxation and social policy issues. These firms, along with international banks and investment companies, and consultancies like McKinsey and Accenture, transmit knowledge and ways of operation from the Core to the Periphery. The professional services sector (law, advertising, accountancy, etc.) can be seen as occupying 'neo-imperial spaces' that function through the medium of English. The discourse of being transnational or global 'is itself a form of manipulation by professionals, operating as it does to universalise the norms and interests of the Core' (Boussebaa 2017) ${ }^{34}$.

The parastatal body, the British Council, 'The United Kingdom's international organisation for cultural relations and educational opportunities ${ }^{35}$ can be seen as a professional service firm promoting UK values, British education and the English language worldwide. Their activities assume that its fundamental cultural values are relevant worldwide, i.e. as a cultura nullius, cohabiting with American values and language. The medium for all activities is English in its British form as universally relevant. The British Council organization recruits its directors from the business world. Its large budget for activities in about 100 countries derives almost exclusively from teaching and examining English, consultancies, and 'intelligence' reports on education worldwide. The British Council, British examination boards, and British publishers are actively expanding their influence on education systems through 'advice' on English learning in schools, promoting English-medium universities and schools, and by organizing annual conferences on 'world education'. It is British government policy to attract increasing numbers of foreign studies to the UK, in competition with Australia and the USA. There are currently 300,000 foreign students at British higher education institutions, 67,000 of them from China. This activity is described by the British government as a major export business.

English is projected as a lingua nullius, a language that everyone needs, and that should be established in basic education worldwide. In British Council policy

'English is now seen as a "basic skill" which all children require if they are fully to participate in 21 st century civil society ... It can now be used to communicate to people from almost any country in the world ... We are fast moving into a world in which not to have English is to be marginalised and excluded.' (Graddol $2006^{36}$ )

Martin Davidson, its Chief Executive, asserts in the Annual Report 2009-10:

\footnotetext{
were established to do. They are complicit in 'The financial scandal that no-one is talking about' (Brooks 2018).

${ }^{34}$ For details of the key areas of activity in the world system, assessed by a scholar in business studies, see Boussebaa 2016.

I have written a comparison of the validity of Graddol's arguments and those used 180 years earlier in India by Macaulay, which strongly influenced colonial education policy. They are disturbingly similar, see Phillipson 2016 b.
} 
"English next India ${ }^{37}$ tells us that from education to the economy, from employability to social mobility, the prospects for India and its people will be greatly enhanced by bringing English into every classroom, every office and every home." (italics added, RP). These false arguments are a re-run of the imperialism of the colonial age (Phillipson, 2016b). The specious assumption is that English is the sole language of globalisation, and in everyone's interest.

It is, of course, a truism that English can be used to resist and combat imperialism as well as to establish it, but the major expansion of English since 1945 has been as an integral constituent of the internationalisation of finance capital and commerce, of NATO, which now operates outside the North Atlantic area, the UN, global media, publishing, academia, schools worldwide, and much else. Churchill's words have been followed up in investments, led by the US, in all of the five domains that he specified, and in establishing structural violence and inequality between the rich North and the majority world in the South, and within countries in fostering a privileged elite that has become obscenely rich.

Language policies that can influence and mitigate these trends are urgently needed. They are under macro level lingua nullius pressure that needs to be resisted at the meso level of higher education institutions and the micro level of how viable solutions are worked on at the chalk face.

\section{Micro level perspectives}

As university staff, it is important to analyse our conditions of employment. There have been major changes in funding, in university management, in policy formation, evaluation and ranking criteria, and internationalisation. These innovations impact on time-honoured principles of university autonomy and academic freedom, on principles of Bildung and Wissenschaft. The increasing use of English in continental Europe creates existential dilemmas for national languages as languages of instruction, of publication, and influence on local knowledge and identities.

Intellectual and cultural life in Europe was international for centuries before it was nationalised. Scholarship traditionally required reading competence in several languages. It is probable that EU policies for research funding and for the creation of a Europe-wide higher education and research area, by means of the Bologna process and its successor schemes, are strengthening the new parameters of university life identified by Collini and summarised earlier, as well as English as the dominant lingua academica.

The increased use of English as a scholarly language throughout continental Europe triggers new patterns of bilingualism and multilingualism. The misguided assumption that English is the sole language of globalisation and

\footnotetext{
37 A follow-up by David Graddol to his earlier, global English Next. The notion that a single British "expert", commissioned by the British Council, can sort out language education in India is neocolonial in itself
} 
internationalisation can be seen in a Report to the European Commission in June 2013 by a High Level Group on the Modernisation of Higher Education. The Report makes many astute recommendations on improving teaching and learning. Other recommendations predictably stress what the EU would like to hear: employability, entrepreneurial and innovative mind-sets, programmes relevant to social and labour market needs, and the strengthening of partnerships between higher education, business and research.

Recommendation 12 refers to 'a sufficient command of English and a second foreign language and intercultural competences' ${ }^{38}$. This implicitly sees English as the sole language of internationalisation. This is a clear instance of the hegemony of English being strengthened without serious consideration being given to other languages of scholarship. In like fashion, policies for the Bologna Process have consistently failed to explicitly address language policy, for instance by promoting bilingual doctorates. The research funding of Horizon 2020 operates similarly: applications are submitted and evaluated exclusively in English. While this procedure seemingly simplifies the process, the monolingual insistence disadvantages users of other languages in international scientific collaboration. It also reduces efficiency and equity in the evaluation process, since the evaluating 'experts' have varying levels of proficiency in English ${ }^{39}$.

All these EU activities and initiatives sanitise English as a lingua nullius, as though the language is value-free, politically disconnected, and merely an instrument that serves all equally well, which is counter-factual at both structural and individual levels. An excessive focus on English promotes historical amnesia, and marginalises other international languages of scholarship.

That English is not global or universal in scientific productivity is shown persuasively in a study of publications in the field of biodiversity conservation (Amano, González-Varo, and Sutherland 2016). The research project at the University of Cambridge identified 75,513 scientific manuscripts on biodiversity conservation on Google Scholar. The number of articles in the top languages was

$\begin{array}{ll}\text { English } & 48,600 \\ \text { Spanish } & 9,520 \\ \text { Portuguese } & 7,800 \\ \text { Chinese } & 4,540 \\ \text { French } & 2,290 .\end{array}$

The valid conclusion from this study is that the notion that in the scientific world, everything of importance is published in English is simply incorrect, and limits the quality of scientific work. In addition to the languages listed, German, Japanese, and Russian are other major languages of scientific creativity and reporting. A second conclusion is that scholars who function exclusively in

\footnotetext{
38 http://ec.europa.eu/education/library/reports/modernisation en.pdf

39

I have a decade of involvement in evaluating applications to the EU and EU-funded research projects, a complex activity because of major differences in professional specialisation and in proficiency in English of other experts.
} 
English are not optimally qualified. This is certainly the case in the language policy field, and in educational research ${ }^{40}$. This demonstrates how unwise and short-sighted it is for education in any continental European country to concentrate exclusively on learning English. This false belief is widespread in many countries, including Denmark, and in many of the activities the EU supports. Likewise, the UK ought to be strengthening the learning of a variety of foreign languages, and building on the heritage languages now present in the country.

The Nordic countries (Denmark, Finland, Iceland, Norway, and Sweden) have a strong tradition of education leading to high levels of proficiency in several foreign languages, particularly English, French, and German, but this richness is being undermined by lingua nullius pressures. Language policy in all five countries has been evaluated extensively in recent years (Hultgren, Gregersen and Thøgersen 2014). A key Nordic declaration on language policy (Nordic Council of Ministers 2006) addresses means for achieving a diversity of goals. It encourages higher educational institutions to develop explicit language policy plans, and to make all residents in their countries aware of their language rights. The overall goal is to ensure the continued vitality of national languages, while simultaneously evolving greater competence in English. Unfortunately the Declaration has little on maintaining the vitality of all languages in each country or on a broader range of foreign language learning.

A Report on parallel language competence, More parallel, please! Best practice of parallel language use at Nordic Universities: 11 recommendations (Nordic Council of Ministers 2018) aims at ensuring that all functions that the national language has fulfilled in academia are maintained, and ensuring that 'international' (i.e. foreign) staff and students develop academic competence in this language alongside using English. The Report can serve to raise language awareness, counteract linguicism $^{41}$, and ensure a vibrant balance between the national language and English. Here follows a summary of the Recommendations for universities in the five Nordic countries.

\footnotetext{
40 A separate issue, which is also of relevance to 'Global Science', is how knowledge of the way biodiversity is understood and conserved in non-Westernised parts of the world, in indigenous knowledge culture and cosmology, and embedded in their languages. The sustainability of our world is dependent on cherishing the multilingualism that has been evolved over centuries, in synergy with cultural and biological diversity. The widespread movement to revitalize minoritised languages is a clear indication of the importance of this heritage (Hinton, Huss, and Roche 2018). Eurocentrism is a limitation, as Indian scholars have been pointing out for many years. 'Revitalization theories and practices are beyond the reach of most endangered language speakers, circulating in the English-language literature and following the geographical contours of both British imperialism and U.S. neocolonialism' (Roche 2018, 276), hence the urgent need to decolonize revitalisation approaches. Email can boost scholarly collaboration worldwide in a virtually infinite range of languages.

41

This term was coined by Skutnabb-Kangas (1988) by analogy with racism and sexism, with comparable hierarchising mechanisms and effects.
} 
1. All universities should have a language policy integrated with its internationalisation policy and that relates to national language policy parameters and the role of the university locally.

2. All universities should have a language policy committee that follows developments continually.

3. A language centre should, on the basis of research criteria, elaborate courses in the local language of relevance for 'international' staff and students, and should ensure the quality of such courses; it should also offer translation and language revision services; it should develop digital resources.

4. International teaching and research staff should be instructed in forms of parallel academic language use, and features of local students' dialogic discourse; they should also be familiarised with the local language of university administration; and progressively acquire competence to function fully in the local language; this should be stipulated in their employment contract.

5. There should be needs analysis in relation to study disciplines and future employment for guest students and for foreign students doing an entire degree; local students should be instructed in the discourse of their academic field in their language and in English, and ideally in additional languages.

6. Elaboration of a specialised needs analysis so as to achieve full parallel competence.

7. Criteria for choice of the language(s) of instruction, for lecturers' language proficiency, reading material, and specification of achievement in each language are needed.

8. Principles for the language of university administration.

9. Strategies for languages of publication.

10. Policies for research dissemination and popularisation nationally and internationally.

11. Elaboration of relevant digital tools for staff and students.

It is significant that these meso level recommendations aim to ensure that English will not be seen as superior to national languages, that the ideology of English as a lingua nullius should be resisted. Aiming at the relevant Nordic language being used by all staff, including 'international' staff, is a bold innovation. For foreign academics employed in Scandinavian and Finnish universities in the 1970s and 1980s, learning to function in the local language was imperative, whereas there has been more acceptance of foreign academics not doing so in recent years.

It is too early to be able to assess how far these recommendations will be implemented effectively. Several universities in the Nordic countries have explicit language policy documents. In some the duty to implement measures is specified, meaning that there is more chance of action emerging. This could, for instance, be relevant in Iceland, where there are serious concerns about Icelandic being replaced by English (Kristinsson 2016).

What is manifestly absent from the document is any consideration of the need in each country to have high-level research and teaching in a range of foreign languages, from Europe and elsewhere. 
In parts of Europe in which there are high levels of proficiency in English, an increased use of English can be seen as linguistic capital accumulation, for the individual and the group. The repertoire of languages in use is expanded, and additive bilingualism or multilingualism is established. By contrast, if English replaces a national language in key functions, in academia, politics, business, or cultural life, to the point where other languages are downgraded and excluded, what takes place is linguistic capital dispossession. It is possible to identify the policies, discourses, and agents involved in such processes, the forces in action locally and externally, hegemonic pressures of coercion and consent, structures and discourses that facilitate new patterns of linguistic governance.

Maintaining the vitality of all languages entails avoiding being brainwashed at the micro level of concepts and discourse patterning originating in English, at the meso level of institutional language policies, overt and covert, and at the macro level of unquestioning faith in the structures and ideologies that strengthen English and market forces and their devastating consequences.

The monolingualism of much linguistic, applied linguistic, and sociolinguistic research, choreographed by interests in the USA and UK, and of research in general in countries in which English is dominant, may serve to consolidate English in covert hegemonic ways that we constantly need to be alert to. Otherwise we may be acting in ways that promote English as a lingua nullius in linguicist ways.

Scholars using English run the risk of being in the same ambivalent position as Churchill, as articulated in two very different lectures, consolidating the power of English while wishing to ensure that universities only serve humane, moral, culturally and politically enlightened purposes. Academics need to analyse whether they are complicit in a system that serves the $1 \%$ rather than all of humanity.

Whether the current dominance of English will continue for more than a few decades is an open question. China has benefited massively from the globalisation of recent decades. It is investing in strengthening its economy worldwide, its military capacity, and party control, while also promoting Chinese soft power worldwide through establishing Confucius Institutes in comparable ways to how Anglo-American policies have promoted English since the $1950 \mathrm{~s}^{42}$.

The rise of China within its huge, diverse state was achieved by comparable means to those used by European and Europeanised states that had a monopoly of the use of military and police force within a territory. In China, military force is in action in Tibet and the Uighur regions, combined with measures to eliminate local languages and cultures. This too has parallels with what Europeans did worldwide. What China will use its increasing power for, and how this will

\footnotetext{
42 Studies of the overall thrust of Confucius efforts worldwide indicate that they are of limited impact in projecting a favourable image of China (Gil 2017). Similarly, a study of the cultural adaptation of Confucius teachers in the UK on short-term contracts reveals poor preparation, poor pay and working conditions, and a poor reception in the host country (Ye 2017).
} 
impact on English in a turbulent 21 ${ }^{\text {st }}$ century' are questions that public policy worldwide needs to address.

Amano, Tatsuya, Juan P. González-Varo, and William J. Sutherland (2016). Languages are still a major barrier to global science. PLoS Biol 14(12): e2000933. doi:10.1371/journal.pbio.2000933.

Bourdieu, P. (1989). La noblesse d'état. Grandes Écoles et esprit de corps. Paris: Les Éditions de Minuit.

Boussebaa, Mehdi (2017). Global professional service firms, transnational organizing, and core/periphery networks. In Professional networks in global governance, ed. L. Seabrooke and L. Henriksen, 233-244. Cambridge: Cambridge University Press.

Brooks, Richard (2018). The financial scandal no-one is talking about, The Guardian, 1 June 2018. https://www.theguardian.com/news/2018/may/29/the-financial-scandalno-one-is-talking-about-big-four-accountancyfirms?utm source=esp\&utm medium=Email\&utm campaign=The+Long + Rea

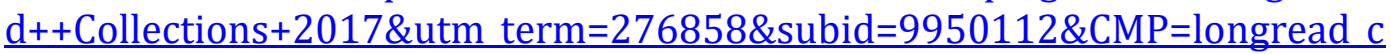
ollection.

Bunce, Pauline, Robert Phillipson, Vaughan Rapatahana, and Ruanni. F. Tupas (eds.) 2016. Why English? Confronting the Hydra. Bristol: Multilingual Matters.

Collini, Stefan 2017. Speaking of universities. London: Verso.

Debray, Régis 2017. Civilisation. Comment nous sommes devenus américains. Paris Gallimard.

Enever, Janet and Eva Lindgren (eds.) 2017. Early language learning. Complexity and mixed methods. Bristol: Multilingual Matters.

Gil, Jeffrey 2017. Soft power and the worldwide promotion of Chinese language learning. Bristol: Multilingual Matters.

Gazzola, Michele 2016. European study for Multilingualism: Benefits and Costs. European Parliament's Culture and Education Committee. http://www.europarl.europa.eu/supporting-analyses.

Graddol, David 2006. English next: Why global English may mean the end of 'English as a Foreign Language'. London: The British Council.

Graddol, David 2010. English next India. London: British Council.

Holroyd, Michael. 1997. Bernard Shaw. The one-volume definitive edition, London: Chatto and Windus.

Kayman, Martin A. 2004. The state of English as a global language: communicating culture. Textual practice 18/1, 1-22.

Kenny, Michael and Nick Pearce 2018. Shadows of Empire. The Anglosphere in British Politics. Cambridge: Polity Press.

Hamelink, Cees 1994. Trends in world communication: on disempowerment and self-empowerment. Penang: Southbound and Third World Network.

Hinton, Leanne, Leena Huss, and Gerald Roche (eds.) 2018. The Routledge Handbook of Revitalization. New York and London: Routledge.

Holm, Erik 2001. The European anarchy. Europe's hard road into high politics. 
Copenhagen: Copenhagen Business School Press.

Hultgren, Anna Kristina, Frans Gregersen and Jacob Thøgersen (eds.) 2014. English in Nordic universities. Ideologies and practices. Amsterdam: John Benjamins.

Judt, Tony 2010. Ill fares the land: A treatise on our present discontents. London: Penguin.

Kenny, Michael and Nick Pearce 2018. Shadows of Empire. The Anglosphere in British politics. Cambridge: Polity Press.

Kristinsson, Ari Páll 2018. English language as 'fatal gadget'. In Bunce et al, 118128.

Lainio, Jarmo, Moa Nordin and Sari Pesonen 2017. Nationella Minoritetsspråk $i$ skolan - förbättrade förudsättningar til undervisning och revitalisering. Betänkande av Utredningen förbättrade möjligheter för elever att utveckla sitt nationella minoritetsspråk. Statens Offentliga Utredningar. SOU 2017: 91 (654 pages, Summary in English, pp. 333-43).

Locke, John 1988 (originally 1690). Two treatises of government. Cambridge: Cambridge University Press.

McCarthy, Thomas 2009. Race, empire, and the idea of human development. Cambridge: Cambridge University Press.

Municio-Larsson, Ingegerd 2000. Science and policy. When does science matter?'. In Phillipson, Robert (ed.), Rights to language: equity, power and education. New York: Lawrence Erlbaum Associates, 127-134.

Nordic Council of Ministers 2018, on behalf of Frans Gregersen et al. More parallel, please!: Best practice of parallel language use at Nordic Universities: 11 recommendations. København: Nordisk Ministerråd. http://norden.divaportal.org/smash/record.jsf?pid=diva2\%3A1203291\&dswid=-7203.

Olthuis, Marja-Liisa, Suvi Kivelä and Tove Skutnabb-Kangas 2013. Revitalizing indigenous languages. How to recreate a lost generation. Bristol: Multilingual Matters.

Patel, Raj and Jason W. Moore 2018. A history of the world in seven cheap things. A guide to capitalism, nature, and the future of the planet. London: Verso.

Patten, Chris 2005. Not quite the diplomat, Home truths about world affairs. London: Allen Lane/Penguin.

Phillipson, Robert 1992. Linguistic imperialism. Oxford: Oxford University Press.

Phillipson, Robert 2001. Global English and local language policies: what Denmark needs. Language Problems and Language Planning, 25/1, 1-24.

Phillipson, Robert 2003. English-only Europe? Challenging language policy. London: Routledge.

Phillipson, Robert 2009. Linguistic imperialism continued. New York \& London: Routledge

Phillipson, Robert 2016a. Linguistic imperialism of and in the European Union. In Revisiting the European Union as an empire, ed. Hartmut Behr and Jannis Stivachtis, London: Routledge, 134-163.

Phillipson, Robert 2016b. Promoting English: Hydras old and new. In Bunce et al, eds, 35-46.

Phillipson, Robert 2017. Myths and realities of European Union language policy. World Englishes, 36/3: 347-349, online 30 October 2017. doi: 10.1111/weng.12270.

Phillipson, Robert 2018. English, the lingua nullius of global hegemony. In The 
politics of multilingualism. Europeanisation, globalisation and linguistic governance, ed. Peter A. Kraus and François Grin. Amsterdam: John Benjamins, 275-304.

Ritzer, George 2011. The McDonaldization of society 6. Thousand Oaks, CA: Sage.

Roche, Gerald 2018. Regional perspectives: Decolonizing and globalizing language revitalization. In Hinton, Huss and Roche (eds.), 275-277.

Salö, Linus, Natalia Ganuza, Christina Hedman, and Martha Sif Karrebæk 2018. Mother tongue instruction in Denmark and Sweden. Language policy, crossfield effects, and linguistic exchange rates. Language Policy 17/4, 591-610.

Saunders, Frances Stonor 1999. Who paid the piper? The CIA and the cultural cold war. London: Granta.

Skutnabb-Kangas, Tove and Robert Phillipson (eds) 2017. Language Rights. Four volumes. London : Routledge.

Skutnabb-Kangas 1988. Multilingualism and the education of minority children. In Skutnabb-Kangas, Tove and Jim Cummins (eds). Minority education: from shame to struggle, Clevedon: Multilingual Matters, 9-44.

Skutnabb-Kangas, Tove, Robert Phillipson, Ajit Mohanty and Minati Panda (eds.) 2009. Social justice through multilingual education. Bristol: Multilingual Matters.

Smith, Richard C. 2003a. 'General Introduction' to Smith, R.C. (ed.), Teaching English as a Foreign Language, 1912-36: Pioneers of ELT, Volume 1. London: Routledge, pp. xi-xxxix.

Smith, Richard C. 2003b. 'Introduction to Volume V' (Introduction to Teaching English as a Foreign Language, 1912-36: Pioneers of ELT, Volume 5). London: Routledge, pp. xi-xxix.

Spooner, Marc and James McNinth (eds.) 2018. Dissident knowledge in higher education. Regina, Canada: University of Regina Press.

Uzgalis, William 2017. John Locke, slavery and Indian lands. http://www.oxfordhandbooks.com/view/10.1093/oxfordhb/97801902369 53.001.0001/oxfordhb-9780190236953-e-41

Verstraete-Hansen, Lisbeth og Robert Phillipson (red.) 2008. Fremmedsprog til fremtiden. Sprogpolitiske udfordringer for Danmark. København: Institut for Internationale Sprogstudier og Vidensteknologi, CBS.

Verstraete-Hansen, Lisbeth og Per Øhrgaard 2017. Sprogløse verdensborgere. Om en uddannelsespolitik, der forsvandt. København: Djøf (Jurist- og Økonomernes Forlag).

Wagnleitner, Reinhold 1994. Coca-Colonization and the cold war. The cultural mission of the United States in Austria after the Second World War. Chapel Hill: University of North Carolina Press.

Wechsler, Alan, 2017. The International-School Surge. The Atlantic, June 5, 2017. https://www.theatlantic.com/education/archive/2017/06/theinternational-school-surge/528792/

Winand, Pascaline 1993. Eisenhower, Kennedy, and the United States of Europe. New York: St. Martin's Press.

Ye, Wei 2017. Taking Chinese to the world. Language, culture and identity in Confucius Institute teachers. Bristol: Multilingual Matters. 